\title{
Neonatal Bullous Urticaria Pigmentosa: Case Report
}

\author{
Neonatal Büllöz Ürtikerya Pigmentoza: Olgu Sunumu \\ Aysun ŞİKAR AKTÜRK, ${ }^{1}$ Rebiay KIRAN, ${ }^{1}$ Sevgiye KAÇAR ÖZKARA, ${ }^{2}$ Gökhan BÜYÜKKALE ${ }^{3}$ \\ Departments of ${ }^{1}$ Dermatology, ${ }^{2}$ Pathology, ${ }^{3}$ Pediatrics, Medical Faculty of Kocaeli University, Kocaeli
}

Submitted / Başvuru tarihi: 09.09.2008 Accepted / Kabul tarihi: 14.10.2008

\begin{abstract}
Mastocytosis is a heterogeneous group of diseases characterized by the abnormal infiltration of mast cells in the skin and other organs. The most common type of cutaneous mastocytosis in children is urticaria pigmentosa. The term "bullous mastocytosis" is used to describe cases with mastocytosis in which bullae was a prominent feature. Systemic involvement is more frequent in this type. If typical lesions and symptoms are absent, the diagnosis of bullous mastocytosis is not always evident and other bullous diseases such as bullous impetigo, primary herpes simplex virus infection, immuno-bullous disease, neonatal lupus, incontinentia pigmenti and erythema multiforme could be considered. The mastocytosis is usually diagnosed with clinical and histopathological examination. In addition, the disease was recognized rapidly and promptly by a simple technique such as Tzanck smear. Here, we report a 20-day-old boy with neonatal bullous urticaria pigmentosa that was diagnosed rapidly with Tzanck smear.
\end{abstract}

Key words: Bullous mastocytosis; Tzanck smear; neonatal.
Mastositoz, mast hücrelerinin deri ve diğer organlarda anormal infiltrasyonu ile karakterize heterojen bir grup hastalıktır. Kutanöz mastositozun çocuklarda en yaygın formu ürtikerya pigmentozadır. Büllöz mastositoz terimi, belirgin özelliği bül olan mastositozlu olguları tanımlamak için kullanılır. Bu tipte sistemik tutulum daha sıktır. Tipik lezyonlar ve semptomlar yoksa büllöz mastositoz tanısını koymak her zaman mümkün olmaz ve büllöz impetigo, primer herpes simpleks virus enfeksiyonu, immüno-büllöz hastalıklar, neonatal lupus, incontinentia pigmenti ve eritema multiforme gibi diğer büllöz hastalıklar ile karışabilir. Mastositoz tanısı genellikle klinik ve histopatolojik inceleme ile konur. Ek olarak, Tzanck smear gibi basit bir teknikle hızlı olarak teşhis edilebilir. Burada Tzanck smear ile hızlı bir şekilde tanı konan, büllöz ürtikerya pigmentozalı 20 günlük bir erkek çocuk bildirilmektedir.

Anahtar sözcükler: Büllöz mastositoz; Tzanck smear; yenidoğan.
Mastocytosis is a heterogeneous group of diseases char-
acterized by the abnormal infiltration of mast cells in
the skin and other organs. ${ }^{[1-3]}$ The most common type of
mastocytosis in childhood is urticaria pigmentosa (UP).
Two variants of UP including classical and bullous type
were described. Bullous type of UP is a rare condition that is characterized by generalized bullous lesions induced by mast cell proteases that cause dermoepidermal separation. ${ }^{[1,4,5]}$

Here, we report a 20-day-old boy with neonatal bullous UP that was diagnosed rapidly with Tzanck smear.

Presented at the 2nd National Pediatric Dermatology Congress, May 3-6, 2006, Kayseri, Turkey (2. Ulusal Pediatrik Dermatoloji Kongresi'nde sunulmuştur, 3-6 Mayıs 2006, Kayseri).

Correspondence (illetişim adresi): Dr. Aysun Şikar Aktürk. Kocaeli Üniversitesi Tıp Fakültesi Dermatoloji Anabilim Dalı, 41380 Kocaeli.

Tel: 0262 - 3037403 Fax (Faks): 0262 - 3038003 e-mail (e-posta): aysun9442@ekolay.net

(c) Trakya Üniversitesi Tıp Fakültesi Dergisi. Ekin Tıbbi Yayıncıık tarafından basılımıstır. Her hakkı sakıdır.

(c) Medical Journal of Trakya University. Published by Ekin Medical Publishing. All rights reserved. 


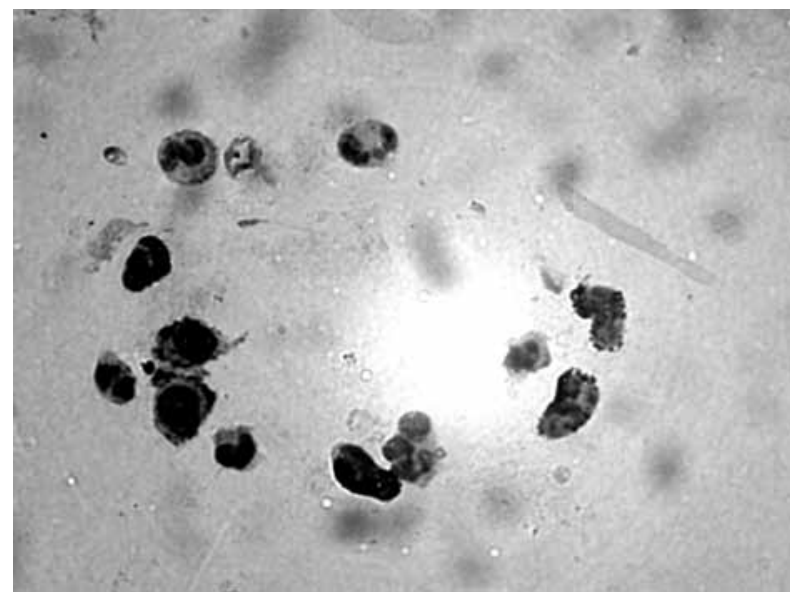

Fig. 1. Tzanck smear showing mast cells and eosinophils (MayGrünwald-Giemsa $x$ 400).

\section{CASE REPORT}

A 20-day-old boy was referred to Kocaeli University Medical Faculty, Pediatrics Newborn Department due to bullous eruptions on his scalp, trunk and limbs that appeared since his birth. He had been delivered with cesarean section at fullterm with no complication. He had no family history of any dermatological or autoimmune diseases. His physical examination was normal. As a first diagnose neonatal Herpes simplex virus infection was considered and intravenous acyclovir treatment was initiated by the pediatrician. However, since the lesions persisted, dermatologists were asked for a consultation. On dermatologic examination of the newborn, some erythematous papules, bullae and erosions covered with thick brown crust on the scalp, face and left inguinal region were detected.

On cytopathological examination of the Tzanck smear of bullous lesions on the scalp revealed mast cells and eosinophils (Fig. 1). No cytopathological finding consistent with Herpes infection was detected. A skin biopsy specimen revealed spongiosis, perivascular and periadnexial mast cell infiltration compatible with mastocytosis (Fig. 2). Hematological and biochemical tests were within normal limits. Abdominal ultrasonography and other radiological examinations were normal. Serological tests revealed unremarkable titres for TORCH. Bullous urticaria pigmentosa was diagnosed based on clinical, laboratory, histopathological and Tzanck smear findings. During hospital stay, the child was treated with anti-histamine drugs, topical corticosteroid and antibiotic cream. His parents were informed about potential mast cell degranulators which must be avoided. The child has been taken under dermatological follow-up every three months for 18-months. In the last few months, hiperpigmented, eryhematous plaques have persisted (Fig. 3). However, bullous lesions or any systemic findings were not detected, although his mother reported rare repetitions of bullous lesions.

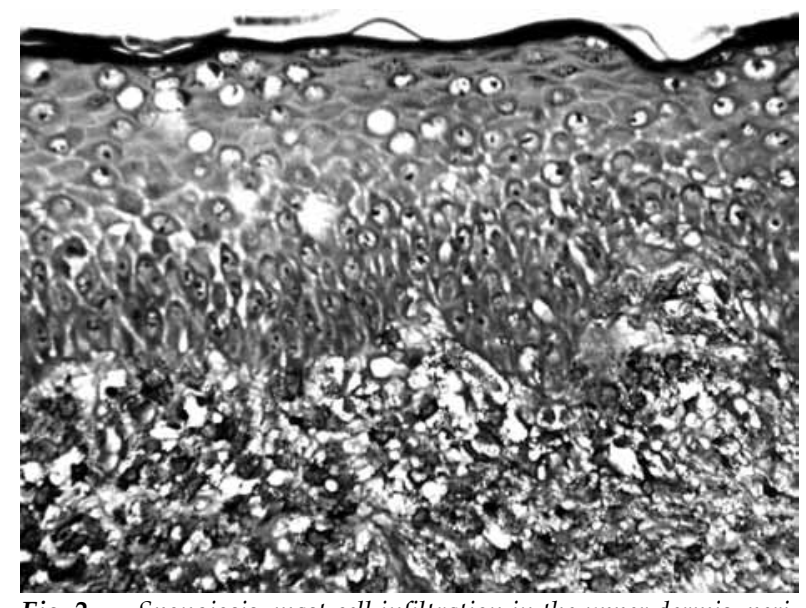

Fig. 2. Spongiosis, mast cell infiltration in the upper dermis, perivascular and periadnexial areas (H-E $x$ 200).

\section{DISCUSSION}

Mast cells that arise in the bone marrow are pluripotential precursor cells. They differentiate in the skin and other peripheral organs under the influence of an array of growth factors, c-kit ligand or mast cell growth factor. ${ }^{[5]}$ Mast cells produce inflammatory cytokines, biogenic amines and proteases. ${ }^{[2,3,6,7]}$

Mastocytosis is a group clinical entity whose features are determined by infiltration of various organs and skin with mast cells. The cutaneous and systemic symptoms such as pruritus, urticaria, wheezing, diarrhea and hypotension are caused by release of mediators by nonallergic mechanism. ${ }^{[3,5-7]}$

The etiology of the mastocytosis is unclear. Recent observations have shown a soluble form of stem cell factor in the skin and suggest an etiologic role for derangements of this growth factor and its receptor. ${ }^{[5,6]}$ In addition, a somatic mutation of the proto-oncogene c-kit that could be responsible for mast cell proliferation has been detected. ${ }^{[2,4,6]} \mathrm{C}$-kit mutation analyses are

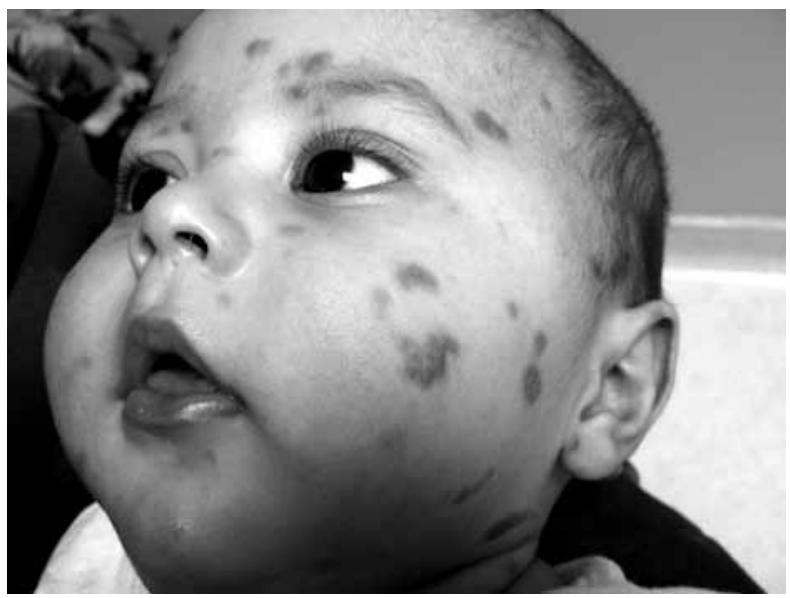

Fig. 3. Hyperpigmented and erythematous papules and plaques on the face at the age of 5 th month. 
important for the therapy and prognosis of mastocytosis. ${ }^{[2]}$

There are four clinical subtypes of cutaneous mastocytosis: mastocytoma, urticaria pigmentosa (UP), diffuse cutaneous mastocytosis and telengiectasia macularis eruptiva perstans (TMEP). The most common type of cutaneous mastocytosis in children is UP. ${ }^{[1-3]}$ There are reports about pseudoxanthomatous mastocytosis in very old research publications. ${ }^{[3]}$ There has been some confusion in the classification of mastocytosis. The term "bullous mastocytosis" has been used to describe cases in which bullae was a prominent feature. Systemic involvement is more frequent in this type. ${ }^{[3,6]}$ However, it was also described as one of the variants of UP in some other reports. ${ }^{[5]}$

The mastocytosis is usually diagnosed with clinical and histopathological examination. It is considered as multiple erythematous and pigmented macules, papules and plaques and localized blistering that vary in size. Darier's sign is positive. Histopathological examination is the gold standard for the diagnosis. ${ }^{[1-3]}$ In addition; the disease is recognized rapidly and promptly by a simple technique such as Tzanck smear. ${ }^{[8]}$ In our case, the diagnosis of bullous UP was made according to the clinical, histopathological and Tzanck smear findings. We diagnosed our case as bullous UP since there were multiple pigmented papules and bullae without systemic involvement.

If typical lesions and symptoms are absent, the diagnosis of bullous mastocytosis is not always evident and other bullous diseases such as bullous impetigo, primary herpes simplex virus infection, immuno-bullous disease, neonatal lupus, incontinentia pigmenti and erythema multiforme could be considered. ${ }^{[9-12]}$ In our case, primary herpes simplex virus infection was diagnosed initially and treated with acyclovir.

Mastocytosis affects infants and children. The onset is usually in the first year of life and even at birth. Prognosis of mastocytosis is related to the onset of the cutaneous lesions and systemic involvement. However, UP has a benign course. ${ }^{[1-3,6]}$ Bullous UP affects only young infants and spontaneous resolution until puberty is the rule, despite alarming appearance. ${ }^{[5,13]}$ Acute mast cell degranulation leads to recurrent bullous eruptions. ${ }^{[5]}$ However, Allison et al. reported bullous mastocytosis, with generalized blistering at birth and death on the 8th day, although there was no systemic involvement. ${ }^{[6]}$ The cause of the death was unknown. Davis et al. ${ }^{[14]}$ reported sudden death in a 3-month-old infant with congenital bullous mastocytosis. There was no systemic involvement of this child, either. In our patient, the lesions were detected at birth with no systemic findings. He is 18 months old now and we made dermatological follow-up every three months until now. In the last few months, hyperpigmented, erythematous plaques persisted, but bullous lesion and systemic findings were disappeared.

In conclusion, children with bullous mastocytosis may have a worse prognosis, therefore early diagnosis is important. Tzanck smear examination can provide rapid diagnosis. Although mastocytosis in childhood is generally a benign disease, children with extensive bullae and neonatal onset of the disease may be at risk of shock and sudden death. We presented a rare form of mastocytosis and would like to emphasize that bullous mastocytosis should alert clinician about the possible risk of shock and sudden death.

\section{REFERENCES}

1. Fernandes EI, de Faria BC, Cartell A, dos Santos BA, Cestari TF. Systemic mastocytosis in childhood: report of 3 cases. J Pediatr (Rio J) 2002;78:176-80.

2. Heide R, Tank B, Oranje AP. Mastocytosis in childhood. Pediatr Dermatol 2002;19:375-81.

3. Hannaford R, Rogers M. Presentation of cutaneous mastocytosis in 173 children. Australas J Dermatol 2001;42:15-21.

4. Walker T, von Komorowski G, Scheurlen W, Dorn-Beineke A, Back W, Bayerl C. Neonatal mastocytosis with pachydermic bullous skin without c-Kit 816 mutation. Dermatology 2006;212:70-2.

5. Mastocytoses. In: Braun-Falco O, Plewig G, Wolff $\mathrm{HH}$, Burgdorf WHC. Dermatology. 2nd ed. Berlin: SpringerVerlag; 2000. p. 1649-56.

6. Murphy M, Walsh D, Drumm B, Watson R. Bullous mastocytosis: a fatal outcome. Pediatr Dermatol 1999;16:452-5.

7. Gupta S, Gilder F, Glazebrook C. Intrapartum management of a patient with urticaria pigmentosa. Int J Obstet Anesth 1998;7:261-2.

8. Oranje AP, Soekanto W, Sukardi A, Vuzevski VD, van der Willigen A, Afiani HM. Diffuse cutaneous mastocytosis mimicking staphylococcal scalded-skin syndrome: report of three cases. Pediatr Dermatol 1991;8:147-51.

9. Johnston GA, Ghura HS, Carter E, Graham-Brown RA. Neonatal erythema multiforme major. Clin Exp Dermatol 2002;27:661-4.

10. Nahmias AJ. Neonatal HSV infection Part I: continuing challenges. Herpes 2004;11:33-7.

11. Bonifazi E, Milioto M, Trashlieva V, Ferrante MR, Mazzotta F, Coviello C. Neonatal pemphigus vulgaris passively transmitted from a clinically asymptomatic mother. J Am Acad Dermatol 2006;55(5 Suppl):S113-4.

12. Patrizi A, Neri I, Guareschi E, Cocchi G. Bullous recurrent eruption of incontinentia pigmenti. Pediatr Dermatol 2004;21:613-4

13. Cook J, Stith M, Sahn EE. Bullous mastocytosis in an infant associated with the use of a nonprescription cough suppressant. Pediatr Dermatol 1996;13:410-4.

14. Davis RJ, Waisman M. Urticaria pigmentosa; report of a case with autopsy examination. AMA Arch Derm 1959;79:649-50. 